\title{
Assessment of gross lesions preservation methods for the direct diagnosis of bovine tuberculosis: a constant search for improvement
}

Nicolás Céspedes Cárdenas

USP FMVZ: Universidade de Sao Paulo Faculdade de Medicina Veterinaria e Zootecnia

Cássia Yumi lkuta ( $\square$ cassiayi@yahoo.com.br)

Universidade de São Paulo https://orcid.org/0000-0002-8543-5219

Vanessa Cristinne Victor Rabaquim

USP FMVZ: Universidade de Sao Paulo Faculdade de Medicina Veterinaria e Zootecnia

Antonio Francisco Souza Filho

Universidade de Sao Paulo Faculdade de Medicina Veterinaria e Zootecnia

\section{Gisele Oliveira Souza}

USP FMVZ: Universidade de Sao Paulo Faculdade de Medicina Veterinaria e Zootecnia

\section{Marcos Bryan Heinemann}

USP FMVZ: Universidade de Sao Paulo Faculdade de Medicina Veterinaria e Zootecnia

José Soares Ferreira Neto

USP FMVZ: Universidade de Sao Paulo Faculdade de Medicina Veterinaria e Zootecnia

\section{Research note}

Keywords: Biosecurity, Bovine tuberculosis, Diagnosis, Samples preservation

Posted Date: January 28th, 2021

DOl: https://doi.org/10.21203/rs.3.rs-154688/v1

License: (9) This work is licensed under a Creative Commons Attribution 4.0 International License.

Read Full License 


\section{Abstract \\ Objectives}

The present study assessed the sensitivity and biosafety of the FTA Elute Card ${ }^{\circledR}$ (FTA) (GE Healthcare) as an alternative preservation method of gross lesions for bovine tuberculosis diagnosis, that can endure large distances and high environmental temperatures, which are found in the Brazilian territory.

\section{Results}

The FTA card was compared to the freezing and sodium borate solution methods to preserve 134 gross lesions samples from slaughterhouses located in three Brazilian states. The calculated value for the sensitivity of sodium borate solution (SBS) stored for 30 days was higher than those estimated for the methods of freezing and SBS stored for 60 days, when the PCR and isolation results were interpreted in parallel $(0.55)$. The FTA cards presented the lowest diagnostic sensitivity and did not inactivate all mycobacteria. Given the rush of a slaughterhouse routine, the quantity of lesions with different pathological stages cannot be measured on each FTA card. Thus, as a preservation method of gross tuberculosis lesions, the FTA cards can present infection risks for people who have direct or indirect contact with them.

\section{Introduction}

Bovine tuberculosis (bTB) is an important zoonosis and generates losses in the production of meat and milk. The Brazilian cattle presents a low prevalence, which varies from $0.36-7.6 \%$ for infected herds and $0.035-0.7 \%$ for infected animals, regardless of the differences of production purpose, animal density and number of properties among states [1].

Given the bacteriological confirmation of bTB by direct diagnostic methods is crucial [2, 3], the preservation of the gross lesions during transportation from the slaughterhouses to the laboratories plays an important role, avoiding the growth of contaminants and preserving mycobacteria.

Chilling, freezing and immersion in saturated sodium borate solution had been studied [2, 3, 4], and are highly recommended by OIE. Although these methods' main goal is to maintain viable mycobacteria for culture, direct diagnosis by molecular techniques represents a fast and sensitive option that can overcome the need of living mycobacteria and the microbial contamination issues.

The FTA Elute Card $^{\circledR}$ (FTA) was developed for purification, preservation, room temperature collection, and transportation of nucleic acids from biological samples, as the chemical formula on the cards promotes cell lysis and proteins denaturation [5]. Despite the cards showed partial lysis for some gram-positive species and Mycobacterium species, inactivation was observed for cell suspensions with densities below $\leq 10^{4} \mathrm{cfu} \mathrm{ml}^{-1}[6]$. Furthermore, the cards presented good efficacy to store and to transport samples for 
the direct detection of Mycobacterium tuberculosis from sputum specimens [7], and to extract DNA of $M$. bovis from bovine tissues [8].

The present study evaluated the sensitivity and biosafety of the FTA cards as a tool for the preservation of gross lesions collected at the slaughterhouses for the direct diagnosis of bTB.

\section{Material And Methods}

\section{Samples processing}

Along seven months, 134 gross lesions were detected and sampled, during the routine inspection of bovine carcasses at slaughterhouses from the states of Santa Catarina (South region), Mato Grosso (Midwestern region) and Paraiba (Northwestern region).

Each lesion was divided and preserved by freezing, immersion in sodium borate solution $\left(134 \mathrm{~g} \mathrm{~L}^{-1}\right)$ for 30 (B30) and for 60 days (B60) and imprinting on FTA Elute Card ${ }^{\circledR}$ (GE Healthcare) (FTA). At the division, several lesions showed various degrees of calcification, which were observed by cutting them with sterile surgical scissors. Twenty-three lesions were too small to be divided into freezing, B30 and B60, then the samples tested for B30 and B60 were fewer than the frozen ones.

For culture, all frozen, B30 and B60 samples were decontaminated with 0.75\% 1-hexadecylpyridinium chloride $[9,10]$, while a piece of $6 \mathrm{~mm}$ in diameter of the FTA card was removed using a skin biopsy punch and suspended in $1 \mathrm{ml}$ of sterile saline, followed by inoculation into Stonebrink and LöwensteinJensen media and incubation at $37^{\circ} \mathrm{C}$.

Isolates with morphological aspects compatible with mycobacteria were suspended in $400 \mu \mathrm{L}$ TE buffer (10 mM Tris, $0.1 \mathrm{mM}$ EDTA pH 8.0) and boiled during $5 \mathrm{~min}$ to expose the DNA. For the clinical specimens, 30 milligrams of each frozen, B30 and B60 lesion sample and a piece of $6 \mathrm{~mm}$ in diameter of each FTA were submitted to a modified DNA extraction protocol [11], which included a pre-digestion with $20 \mu \mathrm{L}$ of proteinase $\mathrm{K}\left(20 \mathrm{mg} \mathrm{mL}^{-1}\right)$ and $100 \mu \mathrm{L}$ of lysozyme $\left(10 \mathrm{mg} \mathrm{mL}^{-1}\right)$.

The identification of Mycobacterium tuberculosis complex (MTC) was performed through PCR with primers INS1 (5'-CGTGAGGGCATCGAGGTGGC-3') and INS2 (5'-GCGTAGGCGTCGGTGACAAA-3') [12], and the 245 bp-amplified-products were observed through agarose gel electrophoresis.

\section{Statistical analysis}

The results of MTC detected by isolation and PCR from frozen samples were considered as gold standard. The sensitivity and specificity for each preservation method were calculated based on the results of isolation and PCR in parallel. Associations between preservation methods and the gold standard were performed by Chi square test. Analogously, Cohen's Kappa index was used to calculate the agreement [13]. All the analysis were performed in R software [14] through the epiR and fmsb packages $[15,16]$. 


\section{Results}

The number of MTC isolates was much higher (50/134) in the frozen samples than in the other preservation methods (Table 1). Given B60 and FTA card presented one isolate each (Table 1), p-value and exact value of Fisher demonstrated a significant statistical difference $(0.4234$ and 0.2289 , respectively). 
Table 1

Sensitivity, specificity and respective confidence intervals $(95 \% \mathrm{Cl})$.

\section{Diagnostic test / preservation} method

\section{Isolation}

\begin{tabular}{|c|c|c|c|c|c|c|}
\hline \multirow[t]{3}{*}{$\mathrm{B} 30^{1}$} & positive & 14 & 2 & 16 & \multirow{3}{*}{$\begin{array}{l}0.30(0.17- \\
0.45)\end{array}$} & \multirow{3}{*}{$\begin{array}{l}0.97(0.90- \\
1.00)\end{array}$} \\
\hline & negative & 33 & 65 & 98 & & \\
\hline & Total & 47 & 67 & 114 & & \\
\hline \multirow[t]{3}{*}{$\mathrm{B} 60^{2}$} & positive & 1 & 0 & 1 & \multirow{3}{*}{$\begin{array}{l}0.02(0.00- \\
0.11)\end{array}$} & \multirow{3}{*}{$\begin{array}{l}1.00(0.92- \\
1.00)\end{array}$} \\
\hline & negative & 46 & 64 & 110 & & \\
\hline & Total & 47 & 64 & 111 & & \\
\hline \multirow[t]{3}{*}{$\mathrm{FTA}^{3}$} & positive & 1 & 0 & 1 & \multirow{3}{*}{$\begin{array}{l}0.02(0.00- \\
0.10)\end{array}$} & \multirow{3}{*}{$\begin{array}{l}1.00(0.93- \\
1.00)\end{array}$} \\
\hline & negative & 54 & 79 & 133 & & \\
\hline & Total & 55 & 79 & 134 & & \\
\hline \multicolumn{7}{|l|}{ PCR } \\
\hline \multirow[t]{3}{*}{ B30 } & positive & 21 & 2 & 23 & \multirow{3}{*}{$\begin{array}{l}0.45(0.30- \\
0.60)\end{array}$} & \multirow{3}{*}{$\begin{array}{l}0.97(0.90- \\
1.00)\end{array}$} \\
\hline & negative & 26 & 65 & 91 & & \\
\hline & Total & 47 & 67 & 114 & & \\
\hline \multirow[t]{3}{*}{ B60 } & positive & 23 & 5 & 28 & \multirow{3}{*}{$\begin{array}{l}0.49(0.34- \\
0.64)\end{array}$} & \multirow{3}{*}{$\begin{array}{l}0.92(0.83- \\
0.97)\end{array}$} \\
\hline & negative & 24 & 59 & 83 & & \\
\hline & Total & 47 & 64 & 111 & & \\
\hline \multirow[t]{3}{*}{ FTA } & positive & 16 & 2 & 18 & \multirow{3}{*}{$\begin{array}{l}0.29(0.18- \\
0.43)\end{array}$} & \multirow{3}{*}{$\begin{array}{l}0.97(0.91- \\
1.00)\end{array}$} \\
\hline & negative & 39 & 77 & 116 & & \\
\hline & Total & 55 & 79 & 134 & & \\
\hline \multicolumn{7}{|c|}{ Isolation and PCR in parallel } \\
\hline \multirow[t]{3}{*}{ B30 } & positive & 26 & 3 & 29 & \multirow{3}{*}{$\begin{array}{l}0.55(0.40- \\
0.70)\end{array}$} & \multirow{3}{*}{$\begin{array}{l}0.96(0.87- \\
0.99)\end{array}$} \\
\hline & negative & 21 & 64 & 85 & & \\
\hline & Total & 47 & 67 & 114 & & \\
\hline
\end{tabular}

${ }^{1}$ sodium borate solution for 30 days, ${ }^{2}$ sodium borate solution for 60 days, ${ }^{3}$ imprinting on FTA cards (FTA Elute Card $\circledast$, GE Healthcare), * exact value of Fisher.
$(95 \% \mathrm{Cl})$
$(95 \% \mathrm{Cl})$

Specificity 


\begin{tabular}{|c|c|c|c|c|c|c|}
\hline \multicolumn{2}{|c|}{$\begin{array}{l}\text { Diagnostic test / preservation } \\
\text { method }\end{array}$} & Positive & Negative & Total & $\begin{array}{l}\text { Sensitivity } \\
(95 \% \mathrm{Cl})\end{array}$ & $\begin{array}{l}\text { Specificity } \\
(95 \% \mathrm{Cl})\end{array}$ \\
\hline \multirow[t]{3}{*}{$\mathrm{B} 60$} & positive & 24 & 5 & 29 & \multirow{3}{*}{$\begin{array}{l}0.51(0.36- \\
0.66)\end{array}$} & \multirow{3}{*}{$\begin{array}{l}0.92(0.83- \\
0.97)\end{array}$} \\
\hline & negative & 23 & 59 & 82 & & \\
\hline & Total & 47 & 64 & 111 & & \\
\hline \multirow[t]{3}{*}{ FTA } & positive & 17 & 2 & 19 & \multirow{3}{*}{$\begin{array}{l}0.31(0.19- \\
0.45)\end{array}$} & \multirow{3}{*}{$\begin{array}{l}0.97(0.91- \\
1.00)\end{array}$} \\
\hline & negative & 38 & 77 & 115 & & \\
\hline & Total & 55 & 79 & 134 & & \\
\hline
\end{tabular}

As freezing method was the gold standard, samples preserved in B30 showed the highest sensitivity for isolation, while the FTA card displayed the lowest sensitivity for all diagnostic tests (Table 1).

The results for "PCR" and "isolation and PCR in parallel" showed no statistical differences among the sensitivities of the preservation methods (Table 1). However, the calculated value for the B30 sensitivity was higher than those estimated for the other preservation methods when the PCR and isolation results were interpreted in parallel (Table 1). For this study we found kappa values below 0.60 , which indicates inadequate agreement (fair to moderate agreement) among the diagnostic protocols. The specificities calculated were always high and statistically equal, but they are not able to represent the test itself because the samples suffered mycobacterial loss, instead of being negative for culture.

\section{Discussion}

According to OIE, confirmation of Mycobacterium bovis infection requires traditional mycobacterial culture. On the other hand, molecular techniques have gained their place among the routine diagnostic tests applied for bovine tuberculosis (bTB).

The FTA cards are expected to provide a safe method for storage and transportation, including mailing, by killing all mycobacteria $[6,7]$. Moreover, they would maintain a high-quality DNA for the direct detection of MTC species $[7,8]$.

The present study observed one isolate of MTC from the FTA card, and showed that this preservation method may offer risks, for it does not guarantee the innocuousness of the sample. Regarding the PCR, the detection of MTC is not dependent on the mycobacteria viability, and whereas the results were similar for the frozen and sodium borate preserved samples, the FTA cards displayed a lower MTC detection.

According to Moura et al. [8], the FTA Elute Micro Card was shown as an optimistic DNA extraction method for its convenience and simplicity. However, the material impregnated on the FTA cards was 
tissue previously submitted to enzymatic digestion [8], which could have increased the available mycobacteria from the tissue compared to an imprinting from the lesion.

The MTC survival on the FTA card and the low PCR detection might be due to the excessive cell tissue and/or mycobacteria in the lesion sample [6]. Nevertheless, measuring the amount of content, from lesions with different pathological stages, on the FTA cards would be challenging in the rush of a slaughterhouse routine.

Regarding the numbers of MTC isolates and of MTC detected by PCR, the freezing method showed better results for culture than molecular techniques, though it is expected to be otherwise or at least the same, considering the viable and unviable mycobacteria available in each sample. However, calcium ions are known to present inhibitory effects on the PCR, especially at high concentrations [17], and several gross tuberculosis lesions were in advanced pathological stages showing various degrees of calcification.

The proportions of MTC isolates for B30 and for B60 compared to the gold standard are $32 \%$ and $2 \%$, and they are quite lower than $82.6 \%$ and $26.1 \%$, respectively, found by Morato et al. [4]. Minerals containing calcium carbonate can remove boron from water supplies by adsorption and coprecipitation processes, accordingly to $\mathrm{pH}$ and boron concentration [18]. Although the concentration of sodium borate solution was the same in both studies, the caseous lesions observed by Morato et al. [4] showed no calcification, differently from the present study.

It is difficult to determine if there was a chemical reaction between the sodium borate and the lesions calcification, and, if any, how it could have affected the lesion samples preservation and the PCR. Even so, a decrease of boron concentration may have diminished the preservation quality of the samples for culture, while a decrease of calcium ions would have improved the PCR detection.

\section{Limitations}

Although the FTA cards offer many advantages as a preservation method, they did not match up to the expectations to preserve gross lesions from slaughterhouses for bovine tuberculosis. They showed an exceptionally low diagnostic sensitivity and can present risks for people who may have contact with them. Furthermore, our findings show that different pathological stages of gross lesions may affect the performances of sodium borate solution preservation properties and the efficiency of molecular diagnosis. Additional studies are necessary to confirm these observations.

\section{Declarations}

\section{Ethics approval and consent to participate}

The present study was approved by the Ethic Committee on Animal Use (CEUA/FMVZ) under the protocol number 2580031016. 


\section{Consent for publication}

Not applicable.

\section{Availability of data and material}

All data are presented in the manuscript.

\section{Competing interests}

The authors report no conflict of interests.

\section{Funding}

The authors thank the financial support of the Coordenação de Aperfeiçoamento de Pessoal de Nível Superior, Brasil (CAPES - Finance Code 001) and FAPESP (Políticas Públicas: processo 2017/50190-1).

\section{Author's contributions}

Mycobacterial isolation and identification: NCC, ASFS, GOS; writing of the manuscript: NCC, CYI, VCVR; coordination of the team: JSFN, MBH. All the authors revised and approved the final version of the manuscript.

\section{Acknowledgements}

Not applicable.

\section{References}

[1] Ferreira Neto JS, Silveira GB, Rosa BM, Gonçalves VSP, Grisi-Filho JHH, Amaku M, Dias RA, Ferreira F, Heinemann MB, Telles EO, Lage AP. Analysis of 15 years of the National Program for the Control and Eradication of Animal Brucellosis and Tuberculosis, Brazil. Semina. 2016; doi:10.5433/16790359.2016v37n5Supl2p3385.

[2] Corner LA. Postmortem diagnosis of Mycobacterium bovis infection in cattle. Vet Microbiol. 1994; doi:10.1016/0378-1135(94)90046-9.

[3] World Organisation For Animal Health - OIE. Chapter 3.4.6. Bovine tuberculosis. In: Manual of diagnostics tests and vaccines for terrestrial animals. 2018. https://www.oie.int/fileadmin/Home/eng/Health_standards/tahm/3.04.06_BOVINE_TB.pdf. Accessed 2 Oct 2019.

[4] Morato F, Ikuta CY, Gonçales AP, Souza GO, Amaku M, Cortez A, Heinemann MB, Ferreira Neto JS. Evaluation of optimal storage time of tuberculous lesions stored in sodium borate. Semina. 2016; doi:10.5433/1679-0359.2016v37n5Supl2p3685. 
[5] GE Healthcare Life Sciences. Whatman ${ }^{\text {TM }}$ FTA $^{\text {TM }}$ Elute Cards. Little Chalfont, Buckinghamshire (UK). 2018. https://cdn.gelifesciences.com/dmm3bwsv3/AssetStream.aspx? mediaformatid=10061\&destinationid=10016\&assetid=23778. Accessed 2 Oct 2019.

[6] Rajendram D, Ayenza R, Holder FM, Moran B, Long T, Shah HN. Long-term storage and safe retrieval of DNA from microorganisms for molecular analysis using FTA matrix cards. J Microbiol Methods. 2006; doi:10.1016/j.mimet.2006.05.010.

[7] Guio H, Okayama H, Ashino Y, Saitoh, H., Xiao P, Miki M, Yoshihara N, Nakanowatari S, Hattori T. Method for efficient storage and transportation of sputum specimens for molecular testing of tuberculosis. Int J Tuberc Lung Dis. 2006;10:906-910.

[8] Moura A, Hodon MA, Soares Filho PM, Issa MA, Oliveira APF, Fonseca Júnior AA. Comparison of nine DNA extraction methods for the diagnosis of bovine tuberculosis by real time PCR. Cienc Rural, 2016; doi:10.1590/0103-8478cr20151489.

[9] Corner LA, Trajstman AC, Lund K. Determination of the optimum concentration of decontaminants for the primary isolation of Mycobacterium bovis. N Z Vet J. 1995; doi:10.1080/00480169.1995.35871.

[10] Ambrosio SR, Oliveira EMD, Rodriguez CAR, Ferreira Neto JS, Amaku M. Comparison of three decontamination methods for Mycobacterium bovis isolation. Braz J Microbiol. 2008; doi:10.1590/S1517-83822008000200008.

[11] Boom R, Sol CJA, Salimans MMM, Jansen CL, Wertheim-Van Dillen PME, Van Der Noordaa J. Rapid and simple method for purification of nucleic acids. J Clin Microbiol. 1990;28:495-503.

[12] Hermans PW, van Soolingen D, Dale JW, Schuitema AR, McAdam RA, Catty D, van Embden JD. Insertion element IS986 from Mycobacterium tuberculosis: a useful tool for diagnosis and epidemiology of tuberculosis. J Clin Microbiol. 1990;28:2051-2058.

[13] Landis JR, Koch GG. The measurement of observer agreement for categorical data. Biometrics. 1977;33:159-174.

[14] R [R Core Team]. R: a language and environment for statistical computing. Version 3.4.3. R. Foundation for Statistical Computing, Vienna. 2017. https://www.r-project.org/. Accessed 2 Oct 2019.

[15] Nakazawa M. Functions for Medical Statistics Book with some Demographic Data. Vienna University of Economics and Business (Wirtschaftsuniversität Wien), Institute for Statistics and Mathematics. 2018 https://cran.r-project.org/web/packages/fmsb/fmsb.pdf. Accessed 2 Oct 2019.

[16] Stevenson M, Nunes T, Sanchez J, Thornton R, Reiczigel J, Robison-Cox J, Sebastiani P, Solymos P, Yoshida K, Jones G, Pirikahu S, Firestone S, Kyle R, Popp J, Jay M, Charles Reynard C. EpiR: Tools for the Analysis of Epidemiological Data. R package version 1.0-14. [place unknown: publisher unknown]. https://CRAN.R-project.org/package=epiR. Accessed 2 Oct 2019. 
[17] Schrader C, Schielke A, Ellerbroek L, Johne R. PCR inhibitors - occurrence, properties and removal. J Appl Microbiol. 2012; doi:10.1111/j.1365-2672.2012.05384.x.

[18] Kobayashi K, Hashimoto Y, Wang SL. Boron incorporation into precipitated calcium carbonates affected by aqueous $\mathrm{pH}$ and boron concentration. J Hazard Mater. 2020; doi:10.1016/j.jhazmat.2019.121183. 